\title{
Critical Success Factors Affecting Malaysia' SMEs through inward FDI: Case of Service Sector
}

\author{
Bahrulmazi Bin Edrak ${ }^{1}$, Behrooz Gharleghi ${ }^{2,3}$, Benjamin Chan Yin Fah ${ }^{2,3}$ \& Marianne Tan ${ }^{2}$ \\ ${ }^{1}$ Global Entrepreneurship Research and Innovation Centre (GERIC), Universiti Malaysia Kelantan, Kuala \\ Lumpur, Malaysia \\ ${ }^{2}$ Faculty of Business and Management, Asia Pacific University of Technology and Innovation, Kuala Lumpur, \\ Malaysia \\ ${ }^{3}$ Centre for the Study of the Economics of Ageing (CSEA), Asia Pacific University of Technology and \\ Innovation, Kuala Lumpur, Malaysia \\ Correspondence: Behrooz Gharleghi, Faculty of Business and Management, Asia Pacific University of \\ Technology and Innovation, TPM, 57000, Bukit Jalil, Kuala Lumpur, Malaysia. Tel: 60-19-615-3515. E-mail: \\ behrooz@apu.edu.my
}

Received: April 8, 2014 Accepted: June 28, 2014 Online Published: July 24, 2014

doi:10.5539/ass.v10n16p131 URL: http://dx.doi.org/10.5539/ass.v10n16p131

\begin{abstract}
Foreign Direct Investment (FDI) is not new to the Malaysian economy. Malaysia's GDP growth rate has increased annually for the past three decades thanks to the emergence of inwards FDI into Malaysia. One sector that has attracted the attention of FDI into Malaysia is Malaysia's growing services sector. This paper will analyze secondary researches that are related to Malaysia's Small Medium Enterprises (SMEs), FDI inflow and services sector. The authors managed to get 182 top managers of selected Malaysia' SMEs in the services sector to take part in this research via questionnaire. The results from the questionnaires were then analyzed using descriptive statistics, as well as a statistical software of SPSS. Using SPSS, the authors managed to identify and analyze the reliability of the data collected using Cronbach's alpha, and to analyze the level of significance for each data using Pearson $r$ Correlation Coefficient. The empirical result shows that the reliability based on Cronbach's alpha is acceptable. Furthermore, the levels of significance for selected variables are positive and significant which resulted in the hypothesis being null rejected and alternative accepted.
\end{abstract}

Keywords: FDI, SMEs, Malaysia, service sector

\section{Introduction}

Amongst the developing nations, Malaysia has had a significant share of the Foreign Direct Investment (FDI) inflows which helped in the country's growth. Foreign Direct Investment occur when an organization invests resources such as capital, knowledge and technology into business activities outside its home country (Hill, 2009).

Malaysia moved towards the services sector since the government knew that it could no longer depend on its manufacturing sector which was facing a 'hollowing out effect' to China. Chantasasawat et al. (2005) describe the "hollowing-out phenomenon" as an event where both foreign and local investors leave their countries to invest in China. Countries in Southeast Asia, especially Malaysia are facing an increasing hollowing-out effect because of China's emergence as an FDI magnet in the manufacturing sector. According to MIDA (2011a), Malaysia has addressed the importance of targeting and developing the services sector in the country as it can serve as an engine of growth to boost and sustain the Malaysian economy in its drive to be a developed nation.

SMEs in the services sector are defined as "enterprises with full-time employees not exceeding 50 OR with annual sales turnover not exceeding RM5 million". To be classified as a Small Enterprise, the organization would need to have "sales turnover between RM200, 000 and less than RM1 million OR full time employees between 5 and 19". Medium Enterprises on the other hand have "sales turnover between RM1 million and RM5 million OR full time employees between 20 and 50". Malaysia's services sectors are made up of the education, hotels, health, waste management, tourism, law, financial and even transportation industries (MIDA, 2011a).

FDI has been one of Malaysia's important sources of income, job availability and has contributed much to 
Malaysia's economic growth towards becoming a developed country (The World Bank, 2009). Lehmann (2002) mentions that the domestic capital formation, as well as stocks of technology and managerial know how of host-countries have been enhanced thanks to FDI. FDI also helps to increase the host-country's access to export markets and is a stable source of external financing. Domestic firms may take advantage of the emergence of new technology when foreign firms introduce new products or processes to the domestic market; and this can indirectly help increase the productivity of the domestic firm (Teece, 1977; Aitken \& Harrison, 1999). According to Mirza and Giroud (2004), foreign firms play a role in encouraging and transferring skills, technology and knowledge which is commonly known as the spillover effect to the domestic firms in the host country.

FDI is an important source of income for a developing country such as Malaysia. FDI has created jobs, decreased the unemployment rate, increased the GDP of Malaysia, and has made Malaysia one the most competitive countries in Asia (Har et al., 2008). However, with the growing amount of FDI coming into Malaysia, will it have an impact on the domestic firms within Malaysia itself? To answer this question, the researcher took the liberty of researching the critical success factors affecting Malaysian SMEs through inward Foreign Direct Investment, especially in the services sector.

FDI can have various positive impacts on the growth and development of the host countries the firm operates in ranging from "direct effects" on employment and training to "spillover" effects whereby indigenous firms acquire knowledge and technology from foreign firms through a variety of transmission mechanisms (Mirza \& Giroud, 2004). Foreign investors or multinational corporations (MNCs) are an important source of spillovers in terms of technology, knowledge, management styles, as well as customer and market selection. Spillovers are defined as positive externalities that benefit domestic firms with the presence of FDI, which can result in productivity increases among domestic firms (Caves, 1974; Zhang et al., 2010).

Hence, the problem that this paper addresses is identifying the critical success factors that domestic firms gain from foreign firms which have invested in Malaysia such as technology spillovers, knowledge transfer, better domestic infrastructure and better performance or productivity from domestic firms thanks to the pressure from foreign investors.

Foreign Direct Investment is an important source of income for the Malaysian economy. There have been worries that Malaysian firms would have difficulties competing with foreign firms, in terms of human resources, skills, knowledge and value chain. However, there have been evidence of knowledge, skills and technology transfers from foreign investors to domestic Malaysian firms, and this has increased the Malaysian firm's competitiveness and productivity in the market. The objectives of this paper is to identify whether technology spill overs, knowledge transfer, better domestic infrastructure and better performance or productivity in domestic firms are the outcome of FDI.

\section{Literature Review}

In this section, previous studies are quoted based on their relevance to the variables under consideration and their effects toward foreign direct investment.

\subsection{Transfer of Technological Know-how}

It is undeniable that FDI introduces new jobs and employment for the citizens of a host-country and contributes to the host-country's capital inflow. "FDI allows the transfer of technology (particularly in the form of new varieties of capital inputs) that cannot be achieved through financial investments or trade in goods and services" by the domestic firms (Loungani \& Razin, 2001). FDI can lead to technology transfer to domestic firms, whereby "domestic firms benefit from the accelerated diffusion of new technology (Teece, 1977). There are also cases whereby domestic firms observe their foreign counterpart's technological know-how, and apply the know-how to the firm's processes; which results in an increase in the domestic firm's productivity.

Technological know-how transfer can also occur when an employee moves from a foreign firm to a domestic firm. When multinationals or foreign investors bring in new technology into an economy, the firm would have spent money on training the employees on how to use the technology. Hence, domestic firms may benefit from technological spillovers by hiring the workers whose training costs have in effect been paid by the multinational (Fosfuri et al., 2001).

Caves (1974) mentioned that the transfer of technology and innovation can be fast if the foreign firm disseminates them faster rather than using the technology to compete with domestic firms by supplying the technology to the domestic firms.

Mirza and Giroud (2004) agree that foreign firms do transfer and encourage the transfer of knowledge, skills and technology in various forms to domestic firms in the host countries, mainly through training, demonstration and 
competitive effects. Transfers or spillovers can be both deliberate such as training of workers, internships, and quality control (QC) enforcement of suppliers; and non-deliberate such as competitive pressures from foreign firms for domestic firms to perform better and by being the benchmark for domestic firms to look up to.

\subsection{Transfer of Knowledge/Knowledge Spill-over}

Glass and Saggi (2002) claim that FDI is one of the most important channels which allow technology to transferred from country to country. According to Aitken and Harrison (1999), employees that were employed by foreign firms or were part of joint ventures or mergers may have gathered knowledge which might not be needed in the foreign firm, but is considered valuable to another firm. Spillovers can take place when workers of foreign firms receive training or accumulate experience while working for the foreign firms, and then move to domestic firms or set up their own enterprise (Gorg \& Strobl, 2005), where they transfer their gained knowledge to the domestic firms. Aitken and Harrison (1999) add that when employees leave the foreign firms they are considered experienced workers, and many domestic firms would love to take advantage of the employee's availability, human capital and knowledge which can be used to help raise the productivity of the domestic firm.

Keller and Yeaple (2003) found out that domestic firms were able to benefit from intra-industry FDI in the US, by using firm-level data for the US. Another researcher, Javorcik (2004) also showed that domestic firms in a country such as Lithuania too benefited from foreign investment in terms of knowledge spill over. Glass and Saggi (2002) provided a formal representation of the movement of trained workers from multinationals to domestic firms as a channel for spillovers by coming up with a model. Glass and Saggi said that workers whom were employed by foreign firms would have acquired knowledge about the firm's technology, and some of the knowledge can be transferred to a domestic firm if the employee switched from working in the foreign firm to a domestic firm.

Gorg and Strobl (2005) however stated that the success of knowledge spillover from foreign firms to domestic firms depends solely on the range of differentiation between the home-country and the host-country's characteristic, especially the way the business operates in.

Spillovers from foreign to domestic firms can also occur due to improved technology or change in the scale of production of domestic firms. Improvements in technology can occur as a result of market transactions between foreign firms and domestic firms, knowledge externalities and also due to the increased pressure to perform and produce better from the foreign firms (Balsvik \& Haller, 2005).

\subsection{Increase in the Productivity of the Domestic Firms}

Damooei and Tavakoli (2006) mentioned that there are two channels whereby FDI can help improve the production efficiency of domestic firms in a host country; technology transfer (as mentioned earlier) and spillover benefits. Spillovers can occur in various ways, such as training of labor and other local staff, public goods characteristics of knowledge and learning the reliability of inputs by watching foreign firms.

Dogan et al. (2010) too agree that foreign investors with superior performance will persuade or promote greater competition in the services industry that the domestic firm operates in, because in order to survive in a very competitive service sector, the domestic firms will have to raise their productivity and performance.

FDI can also promote competition in the domestic input market (Loungani \& Razin, 2001). This takes place when domestic firms are pressured are to improve their performance and productivity in order to compete with the foreign firms and with other domestic firms in order gain more market share and sales. Each organization wants to be the customer's preferred choice. Hence, with the availability of FDI (which adds extra competition to the current domestic one), domestic firms will strive to be better than the other in order to compete with foreign firms. Domestic firms will try to increase their productivity and performance in order to gain competitive advantage over its domestic rivals by copying the success of foreign firms in terms of technology and knowledge.

\subsection{Better Domestic Infrastructures}

According to Tsen (2005), the better the infrastructure of a host country, the more attractive it is to FDI, because good infrastructure can help facilitate the process of activities, and distribution of output. Tsen (2005) adds that the Malaysian government, had "established the necessary infrastructures for the needs of investment from foreign organizations" that have opted to venture into Malaysia; especially in Malaysia's services industry.

Another success factor that Malaysian SMEs gain from FDI is the emergence of well-maintained and quality transportation facilities such as roads, highways, seaports, airports and railway tracks. Roads and highways are important for getting from one city to another. If there were no proper roads and highways, foreign investors 
would not have ventured into Malaysia because the foreign firms need to rely on good and quality roads and highways to conduct activities such as visiting clients, and transporting goods. According to MIDA (2011d), the "Malaysian Highway Authority supervises and executes the design, construction, regulation, operation and maintenance of inter-urban highways in Malaysia"; and "the roads and highways or expressways links all the major townships and potential development areas". The major towns in Malaysia are Kuala Lumpur, Ipoh, Georgetown (Penang), Kuching, Kota Kinabalu, Shah Alam, Seremban and Johor Bahru.

Another infrastructure that attracts FDIs to Malaysia's is the availability of good telecommunication facilities (Wagner, 2005). Malaysia has undergone efforts to increase its internet coverage and speed in Malaysia in order to compete with countries such as Japan and South Korea which have high internet download speeds. Hence, Internet providers such as TM, P1Wimax, Digi, Celcom and Maxis compete with each other in order to provide the best and fastest Internet download speed for their customers. Domestic firms, especially those in the services industry can take advantage of the availability of high speed Internet connection to conduct their business operations. For example, organizations that conduct their business operations online such as click and click and mortar stores, can utilize the availability of the good Internet broadband connection that is available in Malaysia. Dell utilizes the availability of the Internet well in Malaysia by accepting purchases of laptops, desktops and computer accessories online, and sending the details of the laptops purchased to the Dell factory to be assembled. An organization such as Cat Whiskers, which is a Malaysian online boutique store, too uses the Internet to sell its merchandise online. Hence, Cat Whiskers can conduct its business operations such as sales online because of the availability of high speed Internet connection that is one factor that attracts FDI.

\subsection{Better Business Opportunities for Domestic Suppliers}

Moran et al. (2005) showed that one positive impact of FDI on domestic Malaysian suppliers was the presence of vertical technology transfer (VTT) from the foreign firms to domestic firms which are the suppliers. They further mentioned that in "Malaysia's electronics sector, foreign investors helped their local sub-contractors keep pace with modern technologies by assigning technicians to the supplier's plants to help set up and supervise large-volume automated production and testing procedures". The suppliers in services sector too can benefit from VTT especially when the foreign firm depends on the domestic supplier for goods.

\section{Research Methodology}

Five variables discussed in the literature review will be used in this section. They are: (i) Transfer of technological know-how, (ii) Knowledge transfer, (iii) Increase in the productivity of the domestic firms, (iv) Better domestic infrastructure, and (v) Better business opportunities for domestic suppliers. Based on these variables, five hypotheses can be developed and they are written in alternative form. Figure 1 presents the framework.

H1: There is a relationship between transfers of technological know-how with inward Foreign Direct Investment.

H2: There is a relationship between transfers of knowledge with inward Foreign Direct Investment.

H3: There is a relationship between increases in the productivity of the domestic firm with inward Foreign Direct Investment.

H4: There is a relationship between better domestic infrastructures with inward Foreign Direct Investment.

H5: There is no relationship between better business opportunities for domestic suppliers with inward Foreign Direct Investment. 


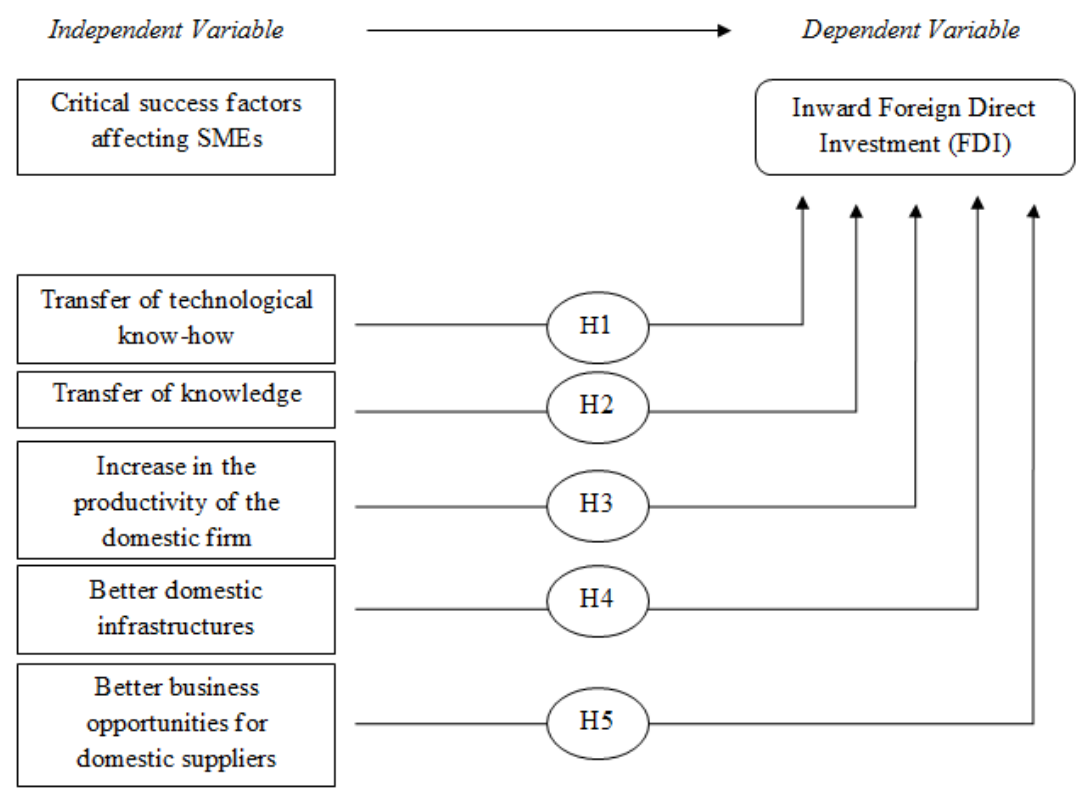

Figure 1. Theoretical framework

\subsection{Data Collection Procedures}

Three methods of questionnaires are conducted; personally administered questionnaires, mail questionnaires, e-mail questionnaires (includes online survey websites). However, out of the 550 questionnaires that were emailed to firms, only 33 replied. This is a 6 percent reply rate which is normal for e-mailed questionnaires. Personally administered questionnaires were conducted face-to-face with the top management as it might ensure a high response rate compared to e-mailed questionnaires. A total of 187 firms were approached to answer the questionnaire face-to-face. Only 123 top level managers of their respective firms agreed to take part in the questionnaire. Questionnaires were also sent via mail, because this method guarantees more responses compared to e-mail questionnaires. 50 questionnaires were mailed by post to selected firms in the states of Penang and Selangor; and only 26 replied. This signals a 52 percent reply for mailed questionnaires.

\subsection{Data Analysis Methods}

The data collected from the questionnaires will be tested and analysed using SPSS (Statistical Package for the Social Sciences) software. Two data analysis methods will be used to justify the primary research objectives; "reliability" using Cronbach's alpha coefficient test, and "the level of significance" using Pearson's Correlation test.

\section{Empirical Findings}

\subsection{Reliability}

To test the reliability of the data, only the interval variables will be used. This is because the interval scaled questions have a more significant effect on this research paper compared to the nominal scaled questions. The interval scaled questions were derived from the theoretical framework of this research paper, and the nominal scaled questions are only demographic based questions which are not of utmost importance regarding this research paper. The table below generates the reliability test for the questionnaires using Cronbach's Alpha.

Table 1. Reliability statistics using Cronbach's alpha

\begin{tabular}{lll}
\hline Cronbach's Alpha & Cronbach's Alpha based on standardized items & No of Items \\
\hline .605 & .612 & 18 \\
\hline
\end{tabular}

According to Table 1, Cronbach's Alpha has a score of .605, which is considered as acceptable. The Cronbach Alpha is based on the 18 interval scaled questions that were derived from the theoretical framework. Cronbach's Alpha "employs the covariance's among the items" in the spss database, and Alpha based on standardized items 
"employs the correlations among items". The researcher of this paper has decided to use Cronbach's Alpha based on standardized items because the alpha score is higher, and because the researcher is interested in the correlations of the data and not the covariance of the data.

Table 2. Item-total statistics

\begin{tabular}{llllcc}
\hline & $\begin{array}{l}\text { Scale } \\
\text { Item Deleted }\end{array}$ & $\begin{array}{c}\text { ifScale Variance if ItemCorrected } \\
\text { Deleted }\end{array}$ & Correlation & $\begin{array}{c}\text { Item-TotalSquared } \\
\text { Correlation }\end{array}$ & $\begin{array}{c}\text { MultipleCronbach's Alpha if Item } \\
\text { Deleted }\end{array}$ \\
\hline Technology 1 & 56.64 & 8.938 & .200 & .117 & .594 \\
Technology 2 & 56.68 & 8.716 & .278 & .159 & .583 \\
Technology 3 & 56.66 & 8.589 & .225 & .143 & .590 \\
Knowledge 1 & 56.60 & 8.772 & .207 & .137 & .593 \\
Knowledge 2 & 56.52 & 8.815 & .152 & .134 & .602 \\
Knowledge 3 & 56.55 & 8.558 & .212 & .162 & .592 \\
Knowledge 4 & 56.74 & 8.637 & .222 & .125 & .590 \\
Productivity 1 & 56.65 & 8.373 & .358 & .204 & .569 \\
Productivity 2 & 56.63 & 8.576 & .234 & .177 & .588 \\
Productivity 3 & 56.69 & 8.846 & .208 & .090 & .592 \\
Productivity 4 & 56.82 & 8.470 & .318 & .194 & .575 \\
Infrastructure 1 & 56.71 & 8.727 & .136 & .150 & .608 \\
Infrastructure 2 & 57.00 & 7.956 & .316 & .283 & .572 \\
Infrastructure 3 & 56.93 & 8.294 & .262 & .284 & .583 \\
Business Opp1 & 56.79 & 8.696 & .228 & .188 & .589 \\
FDI 1 & 56.70 & 8.721 & .135 & .149 & .607 \\
FDI 2 & 56.54 & 8.817 & .154 & .136 & .604 \\
FDI 3 & 56.68 & 8.943 & .201 & .119 & .597 \\
\hline
\end{tabular}

Table 2 shows the various results for the questions asked regarding the Critical Success Factors Malaysian SMEs gain through inward FDI in the services sector. According to Field (2009), the values in 'Cronbach's Alpha if Item Deleted' are the values of the overall alpha $(\alpha)$ if that particular item was not included in the calculation. As seen in table 2, the highest value for Cronbach Alpha if Item Deleted is .608 for the item Infrastructure 1. This is lower compared to Cronbach's Alpha Based on Standardized Items which has a score of .612. This shows that the deletion if the item 'Infrastructure 1' does not increase Cronbach's alpha meaning that it does not improve the reliability of the data. Hence, the researcher will continue using Cronbach's Alpha Based on Standardized Items which has a score of .612, and there will be no need to delete any item to help increase the Cronbach's alpha.

\subsection{Level of Significance}

The results gained from the Pearson's $r$ Correlation Coefficient will be used to test the significance of the data in relating to the hypothesis generated. As mentioned earlier, the significance level used is 0.05 . Hence, the lower a correlation is from 0.05 , the stronger the relationship between the two variables. Table 3 in the following pages shows the Pearson $r$ Correlation Coefficient for all 18 variables which were asked in the questionnaire. The interval scaled and nominal scaled questions were all tested using the Pearson $r$ Correlation Coefficient.

Table 3. Pearson's $r$ correlations coefficient of FDI with selected variables

\begin{tabular}{lllll}
\hline No & Variable & Results & & \\
\hline 1 & Transfers of technological know-how & $r=0.209$ & $\rho=0.005$ & $\mathrm{~N}=182$ \\
2 & Transfers of knowledge & $r=0.288$ & $\rho=0.000$ & $\mathrm{~N}=182$ \\
3 & Productivity of the domestic firms & $r=0.246$ & $\rho=0.001$ & $\mathrm{~N}=182$ \\
4 & Better domestic infrastructures & $r=0.223$ & $\rho=0.002$ & $\mathrm{~N}=182$ \\
5 & Better business opportunities & $r=0.196$ & $\rho=0.008$ & $\mathrm{~N}=182$ \\
\hline
\end{tabular}


Based on the table above, it can be seen that all variables has a positive and significant relationship towards FDI as the level of significances are below 0.05 . Based on the result in table 3, hypotheses testing can be summarized as follow:

Table 3. Overall results for hypotheses testing

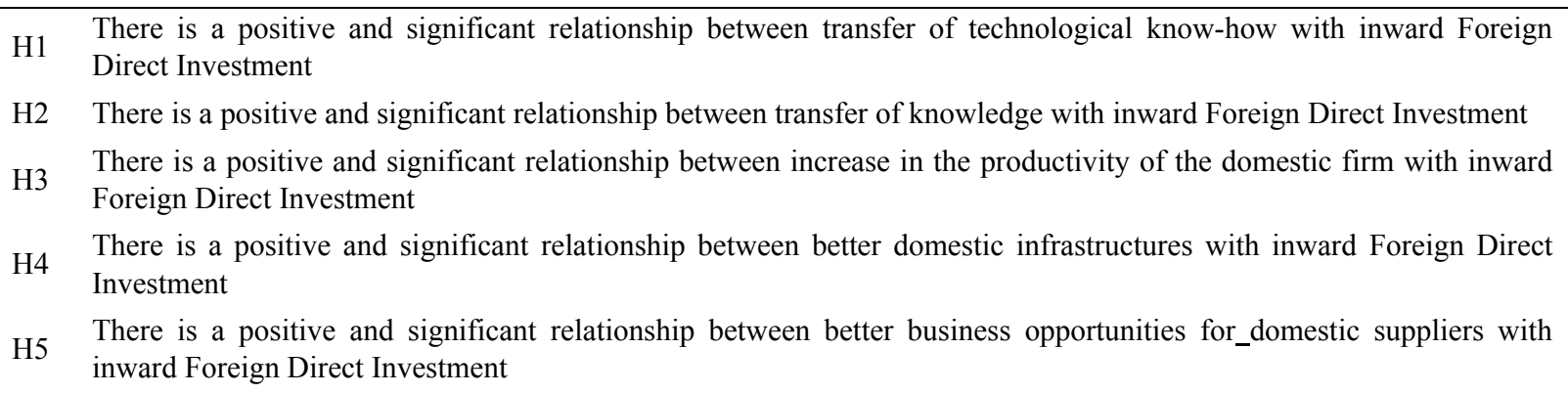

\section{Conclusion}

The main aim of this paper was to investigate whether there is any relationship between technology transferring, knowledge transferring, productivity, infrastructure, and business opportunity with foreign direct investment using Cronbach's Alpha and Pearson correlation tests. Reliability analysis using Cronbach's alpha resulted in the score of 0.612 which is considered as acceptable rate. Finally, Pearson's $r$ Correlation Coefficient was used to the test the level of significance to accept or reject the null hypothesis. The results showed that all five hypotheses had null hypothesis rejected, meaning that the alternative hypotheses are accepted. Furthermore, this paper provided a clearer and in-depth knowledge regarding the success factors affecting Malaysian SMEs via FDI. Additionally, the paper resulted in an in-depth understanding regarding Malaysian SMEs in the service industry; such as the automotive, education, and other service sectors and how technology and knowledge are transferred from foreign to domestic firms; for example, via transfer of technology know-how and by hiring employees with experience working in foreign firms.

\section{References}

Aitken, B. J., \& Harrison, A. E. (1999). Do Domestic Firms Benefit from Foreign Direct Investment? Evidence from Venezuela. The American Economic Review, 89(3). http://dx.doi.org/10.1257/aer.89.3.605

Balsvik, R., \& Haller, S. A. (2005). Foreign Firms and Host-Country Productivity: Does the Mode of Entry Matter? Retrieved from http://www.noits.org/noits05/Balsvik.pdf

Caves, R. E. (1974). Multinational Firms, Competition, and Productivity in Host-Country Markets. Economica, New Series, 41(162), 176-193. http://dx.doi.org/10.2307/2553765

Chantasasawat, B., Fung, K. C., \& Iizaka, H. (2005). The Giant Sucking Sound: Is China Diverting Foreign Direct Investments from Other Asian Economies? Department of Economics, UCSC, UC Santa Cruz. Retrieved from http://escholarship.org/uc/item/26414163

Damooei, J., \& Tavakoli, A. (2006). The Effects of Foreign Direct Investment and Imports on Economic Growth: A Comparative Analysis of Thailand and the Philippines (1970-1998). The Journal of Developing Areas, 39(2), 79-100. http://dx.doi.org/10.1353/jda.2006.0002

Dogan, E., Wong, K. N., \& Yap, M. M. (2010). Turnover, Ownership and Productivity in Malaysian Manufacturing. Department of Economics. Monash University, Discussion Paper 13/10.

Field, A. (2009). Discovering Statistics Using SPSS (3rd ed.). London, Sage Publications.

Fosfuri, A., Motta, M., \& Ronde, R. (2001). Foreign Direct Investment and Spillovers through Workers' Mobility. Journal of International Economics, 53, 205-222. http://dx.doi.org/10.1016/S0022-1996(00)00069-6

Glass, A. J., \& Saggi, K. (2002). Multinational Firms and Technology Transfer. Scandinavian Journal of Economics, 104, 495-513. http://dx.doi.org/10.1111/1467-9442.00298

Gorg, H., \& Strobl, E. (2005). Spillovers from Foreign Firms through Worker Mobility: An Empirical Investigation. The Scandinavian Journal of Economics, 107(4), 693-709. http://dx.doi.org/10.1111/j.14679442.2005.00427.x 
Har, W. M., Teo, K. L., \& Yee, K. M. (2008). FDI and Economic Growth Relationship: An Empirical Study on Malaysia. International Business Research, 1(2), 961-985.

Hill, C. W. L. (2009). International Business: Competing in the Global Marketplace (8th ed.). New York, McGraw-Hill.

Javorcik, B. S. (2004). Does Foreign Direct Investment Increase the Productivity of Domestic Firms? In Search of Spillovers through Backward Linkages. American Economic Review, 94(3), 605-627. http://dx.doi.org/10. 1257/0002828041464605

Keller, W., \& Yeaple, S. (2003). Multinational Enterprises, International Trade, and Productivity Growth: Firm-level Evidence from the United States. NBER Working Paper no. 9504.

Lehmann, A. (2002). Foreign Direct Investment in Emerging Markets: Income, Repatriations and Financial Vulnerabilities. International Monetary Fund. Working Paper 02/47.

Loungani, P., \& Razin, A. (2001). How Beneficial Is Foreign Direct Investment for Developing Countries? Finance and Development: A Quarterly Magazine for the IMF, 38(2), 1-8.

MIDA. (2011a). Invest in Malaysia: Services Sector Overview. Retrieved from http://www.mida.gov.my/env3/ index.php?page $=$ services-sector

MIDA. (2011d). Invest in Malaysia: Highways. Retrieved from http://www.mida.gov.my/env3/index.php? page $=$ highways

Mirza, H., \& Giroud, A. (2004). Regional Integration and Benefits from Foreign Direct Investment in ASEAN Economies: The Case of Viet Nam. Asian Development Bank, Asian Development Review, 21(1), 66-98.

Moran, T. H., Graham, E. M., \& Blomstrom, M. (Eds.). (2005). Does Foreign Direct Investment Promote Development? United States of America, Peterson Institute (pp. 159-174). United States of America, Peterson Institute for International Economics.

Teece, D. J. (1977). Technology Transfer by Multinational Firms: The Resource Cost of Transferring Technological Know-how. Economic Journal, 87(346), 242-261. http://dx.doi.org/10.2307/2232084

The World Bank. (2009). Malaysia Economic Monitor: Repositioning for Growth. Retrieved from http://www. wds.worldbank.org/external/default/WDSContentServer/WDSP/IB/2009/11/17/000334955_200911170129 24/Rendered/PDF/516240ESW0WHIT1 sitioning0For0Growth.pdf

Tsen, W. H. (2005). The Determinants of Foreign Direct Investment in the Manufacturing Industry of Malaysia. Journal of Economic Cooperation, 26(2), 91-110.

Wagner, H. (2005). Globalization and Financial Instability: Challenges for Exchange Rate and Monetary Policy. International Journal of Social Economics, 32(7), 616-638. http://dx.doi.org/10.1108/03068290510601144

Zhang, Y., Li, H., Li, Y., \& Zhou, L. (2010). FDI Spillovers in an Emerging Market: The Role of Foreign Firms' Country Origin Diversity and Domestic Firms' Absorptive Capacity. Strategic Management Journal, 31, 969-989.

\section{Copyrights}

Copyright for this article is retained by the author(s), with first publication rights granted to the journal.

This is an open-access article distributed under the terms and conditions of the Creative Commons Attribution license (http://creativecommons.org/licenses/by/3.0/). 